\title{
PLATAFORMAS INTERATIVAS DIGITAIS PARA PROMOÇÃO DE PRÁTICAS LEITORAS NO ENSINO FUNDAMENTAL: POTENCIALIDADES PARA FORMAÇÃO LEITORA E LETRAMENTO DIGITAL
}

\author{
DIGITAL INTERACTIVE PLATFORMS TO PROMOTE READING PRACTICES IN \\ ELEMENTARY SCHOOL: POTENTIALITIES FOR READER TRAINING AND DIGITAL \\ LITERACY
}
PLATAFORMAS DIGITALES INTERACTIVAS PARA PROMOVER LAS PRÁCTICAS DE LECTURA EN LA EDUCACIÓN PRIMARIA: POTENCIALIDADES PARA LA FORMACIÓN DE LECTORES Y LA ALFABETIZACIÓN DIGITAL

Carine Mello da Silva ${ }^{1}$

Hellen Boton Gandin²

Ana Paula Teixeira Porto ${ }^{3}$

\begin{abstract}
RESUMO
A formação de leitores é um desafio a professores na educação básica, principalmente na era da cibercultura, que, com ferramentas e recursos interativos, demanda a criação de novas possibilidades para a promoção de leitura no ambiente escolar e também fora dele. Nesse sentido, esse trabalho tem por objetivo apresentar possibilidades de prática de mediação de leitura com exploração de jogos digitais que podem ser construídos com exploração de ferramentas disponíveis em duas plataformas: a ELO e a WORDWALL, selecionadas como objetos de investigação. A pesquisa parte de uma abordagem teóricocrítica sobre jogos digitais e formação leitora, contemplando referência a objetivos da leitura na educação básica - etapa do ensino fundamental, ao letramento digital e a associação entre leitura e tecnologias; em seguida, apresenta uma ilustração de potencialidades dessas plataformas para criação de atividades de promoção de leitura. A partir da análise, observa-se que as plataformas são potenciais recursos que podem ser incorporados às práticas de leitura do ensino fundamental, pois por meio das telas, a interatividade, motivação, ludicidade, concentração e atenção são possíveis e contribuem para a exploração e compreensão do que se lê. Contudo, o bom uso delas depende de criatividade, inovação e abordagem centrada em habilidades de leitura.
\end{abstract}

PALAVRAS-CHAVE: Formação de leitores. Ensino Fundamental. Plataformas interativas digitais. ELO. WORDWALL.

\section{ABSTRACT}

The formation of readers is a challenge for teachers in basic education, especially in the era of cyberculture, which, with interactive tools and resources, demands the creation of new possibilities for promoting reading in the school environment and beyond. In this way, the work aims to present possibilities of reading mediation practice with exploration of digital games that can be built using tools available in two platforms: ELO and WORDWALL, selected as objects of investigation. The research is based on a theoretical-critical approach on digital games and reading training, contemplating a reference

\footnotetext{
1 Graduada em Pedagogia e Mestranda do Programa de Pós-graduação - Mestrado em Educação, da URI, campus de Frederico Westphalen, RS. E-mail: kakamellodasilva@hotmail.com

2 Graduada em Letras - Inglês e Mestranda do Programa de Pós-graduação-Mestrado em Educação, da URI, campus de Frederico Westphalen, RS. E-mail: hellengandin@gmail.com

${ }^{3}$ Doutora e Mestre em Letras. Pesquisadora e docente do Programa de Pós-graduação - Mestrado e Doutorado em Educação da Universidade Regional Integrada (URI) - campus de Frederico Westphalen, RS. E-mail: anapaula@uri.edu.br
} 
to reading objectives in basic education - elementary school stage, to digital literacy and the association between reading and technologies; then, it presents an illustration of the potential of these platforms for creating reading promotion activities. From the analysis, it is observed that platforms are potential resources that can be incorporated into elementary school reading practices, because through the screens, interactivity, motivation, playfulness, concentration and attention are possible and contribute to exploration and understanding of what is read. However, the good use of platforms depends on creativity, innovation and an approach centered on reading skills.

KEYWORDS: Reader training. Elementary School. Digital interactive platforms. ELO. WORDWALL.

\section{RESUMEN}

La formación de lectores es un desafío para los docentes de educación básica, especialmente en la era de la cibercultura, que, con herramientas y recursos interactivos, demanda la creación de nuevas posibilidades para promover la lectura en el ámbito escolar y más allá. En este sentido, este trabajo tiene como objetivo presentar posibilidades de práctica de mediación lectora con exploración de juegos digitales que se pueden construir con la exploración de herramientas disponibles en dos plataformas: ELO y WORDWALL, seleccionadas como objetos de investigación. La investigación se basa en un enfoque teórico-crítico sobre los juegos digitales y la formación lectora, incluyendo la referencia a los objetivos de lectura en la educación básica - etapa escolar primaria, a la alfabetización digital y la asociación entre lectura y tecnologías; luego, presenta una ilustración del potencial de estas plataformas para crear actividades de promoción de la lectura. A partir del análisis, se observa que las plataformas son recursos potenciales que se pueden incorporar a las prácticas de lectura de la escuela primaria, porque a través de las pantallas, la interactividad, la motivación, la alegría, la concentración y la atención son posibles y contribuyen a la exploración y comprensión de lo que se lee. Sin embargo, su buen uso depende de la creatividad, la innovación y un enfoque centrado en las habilidades lectoras.

PALABRAS CLAVE: Formación de lectores. Enseñanza fundamental. Plataformas digitales interactivas. ELO. WORDWALL.

\section{CONSIDERAÇÕES INICIAIS}

No contexto educacional brasileiro, a formação de leitores continua sendo um desafio a professores na educação básica não apenas porque dados de avaliações e pesquisas, como as do Programa Internacional de Avaliação de Estudantes - PISA (2018) e do Instituto Pró-Livro (2020), sinalizam para deficiências de leitura e pouco dedicação a ela - especialmente a de livros, mas também pela necessidade de investimento em novas possibilidades de leitura e de sua prática na escola. Há crescimento substancial de novos suportes digitais para leitura e esta sendo buscada na internet para atualização de informações, aponta a pesquisa do Instituto PróLivro (2020), o que indica um caminho necessário para ampliação de práticas de leitura correlacionadas a ferramentais da rede.

Nessa perspectiva, uma questão que urge relaciona-se a metodologias centradas na interação digital entre leitor e texto como forma de motivação para leitora. Assim, pode-se contemplar os jogos digitais para fortalecimento de práticas leitoras na escola, em contextos online e off-line que permitam o contato prazeroso no aluno com a leitura através de exploração de práticas associadas aos traços comuns de jogos digitais. A busca pela construção de jogos, 
considerando os recursos digitais acessíveis disponibilizados pela rede, está relacionada a um ponto central: a necessidade de encontrar novas formas de explorar a leitura no contexto deste século marcado pela cibercultura, pois as novas tecnologias trazem novas formas de ver e ler 0 mundo e consequentemente interferem no modo de aprender e de ensinar.

Sob esse viés de abordagem, defende-se a ideia de que associar tecnologias à leitura mostra-se uma alternativa necessária dado o fato de a inclusão digital ser um fenômeno crescente em todas as camadas sociais e faixas etárias. Apesar disso, deve-se reconhecer que essa articulação carece de consolidação, pois "parece haver ainda algum caminho a percorrer para que a união entre a tecnologia e a leitura se efetue em pleno, beneficiando alunos e docentes que partem à descoberta de percursos potencializadores de novos significados em suporte digital." (MELÃO, 2010, p. 85). Assim, é necessário investir no letramento digital em práticas de leitura para alunos da educação básica como forma de ampliação do contato do aluno a dispositivos tecnológicos digitais e especialmente a novos formatos de trabalho com a leitura.

Considerando esse cenário, este trabalho tem por objetivo apresentar possibilidades de prática de mediação de leitura com um teor inovador, voltadas para a utilização de recursos tecnológicos tanto de informação quanto comunicação, buscando, assim, despertar o prazer e 0 interesse dos alunos pela leitura. Assim, dá-se espaço para referência a jogos digitais que podem ser construídos com exploração de ferramentas disponíveis em duas plataformas: a ELO4 e a WORDWALL ${ }^{5}$ que selecionamos como objeto de investigação. Para atender a sua proposta, a pesquisa parte de uma abordagem teórico-crítica sobre jogos digitais e formação leitora, contemplando referência a objetivos da leitura na educação básica - etapa do ensino fundamental, ao letramento digital e a associação entre leitura e tecnologias; em seguida, apresenta uma ilustração de potencialidades dessas plataformas para criação de atividades de promoção de leitura. Nas considerações finais, ressaltam-se reflexões sobre como as duas plataformas dinamizam as práticas de leitura centradas na formação de leitores.

\footnotetext{
${ }^{4}$ A plataforma ELO, disponível no site https://elo.pro.br/cloud/, é um Sistema de Autoria Aberto criada de forma livre e gratuita para o ensino de línguas online, mas que também possibilita a criação de atividade para outras áreas de ensino.

${ }^{5}$ A plataforma WORDWALL, que possui acesso livre e planos pagos para criação de atividades interativas, é acessivel no site https://wordwall.net/
} 


\section{JOGOS DIGITAIS E FORMAÇÃO LEITORA}

Ao objetivar o uso de tecnologias digitais no ensino, pode-se incluir os jogos interativos que, com peculiaridades que vão desde o formato colorido e atrativo à estruturação de um complexo de ações de um jogador para ganhar o game, podem ser ferramentas profícuas para a formação de leitores. Também é pertinente pensar na ludicidade dos jogos como forma de atrair a atenção discente para aprendizagens diversas. Através de jogos, é possível desenvolver a afetividade e a intelectualidade dos alunos, aprimorando sua capacidade cognitiva, que é necessária para a atividade de leitura, uma vez que "o jogo proporciona avanços nos processos de aprendizagem e desenvolvimento" (TEZANI, 2006, p. 2) à medida que proporciona desafios aos alunos, estimulando-os a alcançar estágios mais elevados de raciocínio. $O$ apelo lúdico, associado a outros elementos de leitura, é, pelo menos, uma forma de sedução para leitura.

No entanto, deve-se salientar que não é qualquer jogo uma ferramenta capaz de estimular a intelectualidade do aluno, desenvolvendo sua capacidade de raciocínio e criticidade, e de, portanto, contribuir para a formação do leitor. Se os jogos não apresentarem desafios ao pensamento dos educandos, questões de leitura e interpretação calcadas no binômio linguagem/estrutura do texto e conteúdo/temática e fundamentadas especialmente na leitura do texto, na reflexão, no fazer pensar sobre o que se fala, como se fala e os efeitos de sentido produzidos, os jogos não se constituem em instrumentos propícios para a formação de leitores críticos. Se forem apenas interativos e lúdicos, voltados a brincadeiras ou a dados informativos e não proposições reflexivas, não são ferramentas pertinentes ao desenvolvimento da leitura crítica. Seriam apenas atividades de compreensão ou de passatempo sem foco na aprendizagem significativa.

Ainda sobre essa perspectiva, é preciso pontuar que muitos jogos buscam "enfatizar conteúdos curriculares, sem se preocupar com a interface, com a qualidade das imagens, jogabilidade e interatividade" (ALVES, 2008, p. 4), assinalando uma má qualidade do recurso que, para fins de formação, deveria associar a aprendizagem com a ludicidade. Como explica Alves (2008), há um desencontro entre "jogos para aprender" e "jogos para divertir", ocasionado muitas vezes pela ênfase dada ou aos objetivos pedagógicos ou aos de entretenimento e diversão. Por isso nem todos os jogos focados na leitura de um texto literário, como um romance, por exemplo, serão objetos pertinentes à formação de leitores. 
Como os jogos digitais são reconhecidos como materiais para uso no contexto escolar, é importante observar a seleção desses recursos quando objetivamos a formação de leitores na escola, pois como destaca Burlamaque (2006, p. 80)

\footnotetext{
0 primeiro passo para a formação do hábito de leitura na escola diz respeito à seleção de material, que deverá servir para informação e recreação, não ser imposto como obrigação, uma vez que a passagem pela escola, muitas vezes, é a única oportunidade que 0 aluno tem de entrar em contato com a leitura.
}

A perspectiva de sedução que deve ser desenvolvida pela escola também é defendida por Kleiman (2002, p. 25) ao afirmar que, no processo de o professor procurar meios para interessar o aluno na leitura de livros, uma medida adequada é a de tornar "a atividade de leitura o mais atraente possível". Essa atratividade, nos jogos digitais, não deve estar relacionada apenas ao uso de cores, imagens, animações ou hipertextos, tão requisitadas pelos nativos digitais que chegam às escolas, mas também ao que se propõe aos alunos tanto nas regras ao jogador quanto nos desafios, nos quais questões de leitura do texto literário em si, preferencialmente na sua forma integral, são indispensáveis.

Se por um lado a sedução aos alunos para o ato de ler é uma questão importante, por outro a leitura crítica também se faz necessário como competência fundamental a ser explorada durante toda educação básica a partir de diferentes metodologias e instrumentos. De acordo com Base Nacional Comum Curricular (2017) para área de Linguagens, especificamente no componente de Língua Portuguesa, o trabalho com o texto, em perspectivas enunciativodiscursivas na abordagem, deve ser central como forma de "relacionar os textos a seus contextos de produção e o desenvolvimento de habilidades ao uso significativo da linguagem em atividades de leitura, escuta e produção de textos em várias mídias e semioses" (BRASIL, 2017, p. 69). Isso indica, quanto à leitura de textos, que as práticas devem suportes, linguagens e gêneros variados de forma a oportunizar o aluno um diálogo com práticas sociais distintas.

Chartier (2009, p. 35) afirma que "o ensino da leitura é meio de transformar os valores e os hábitos dos grupos sociais que são o seu alvo". A leitura deve ser apresentada ao aluno como uma prática transformadora, que está além da decodificação das palavras agrupadas nas folhas dos livros e que o sentido do texto não é somente o que o autor quis apresentar, pois a significação também depende do que os sujeitos, como seres carregados de vivências e experiências, compreendem e agregam sentido no ato da leitura. Assim, Chartier explicita esse mistério que é a leitura e o ato de ler: ler no amplo sentido, não somente para desvendar os símbolos do texto sem permitir uma internalização do que se lê: 
Ler é dar sentido de conjunto, uma globalização e uma articulação aos sentidos produzidos pelas sequencias. Não é encontrar o sentido desejado pelo autor, o que implicaria que 0 prazer do texto se originasse na coincidência entre 0 sentido desejado e o sentido percebido, em um tipo de acordo cultural, como algumas vezes se pretendeu, em uma ótica na qual o positivismo e o elitismo não escaparão a ninguém. Ler é, portanto, constituir e não reconstituir um sentido. (2009, p. 108)

Ainda é preciso considerar o momento atual em que significativas transformações tecnológicas ocorrem, transformando hábitos e padrões de comportamento, o que também interfere no modo de ler e ensinar a ler. Nesse sentido, é importante repensar sobre os conceitos já findados, como é o caso da formação de leitores. Em uma era digital, na qual as consequências desta era já são visíveis aos nossos olhos, Rösing (2016, p. 38) esclarece as novas formas de leituras necessárias atualmente, quando diz que:

\begin{abstract}
Além do que convencionalmente chamamos de texto, é preciso ler e escrever gráficos, imagens, sons, números, setas, sinais, cores, programas de computadores, aplicativos etc. estamos diante de uma complexidade tamanha de leituras e escritas que solicitam outros processos de alfabetização e letramentos digitais, sempre no plural.
\end{abstract}

Esse contexto exige então novos posicionamentos sobre como trabalhar na escola a formação leitora, pois os professores são instigados a encontrar possibilidades que auxiliem na busca por uma formação de qualidade a crianças, e nesse sentido o letramento digital é um dos caminhos que requerem novas formas de ensino. Rösing (2016, p. 43) elucida esse aspecto ao afirmar que:

O letramento digital requer um repertório aberto de manipulação e inferência no texto. Estamos diante de um leitor que soma, que de muitas e diferentes maneiras modifica e amplia o texto. $O$ nível de letramento aumenta quando o sujeito é capaz de manipular igualmente texto e suporte, explorando as possibilidades do hipertexto num continuum.

O letramento digital leva a compreender 0 que as tecnologias podem possibilitar em convergência com as formas de letramentos tradicionais, que não seriam capazes de nos proporcionar o mesmo efeito. Postar, compartilhar, curtir, são práticas que viralizam e que, quando mal manuseadas, podem chegar em um âmbito assustador, causando então uma exposição não desejada, o que ocorre frequentemente por meio das redes sociais e se refere a lacunas no letramento digital. Saber filtrar informações, lidando com o que é verídico e o que não é tão confiável, aceitando diferenças e convivendo com a diversidade, são possibilidades apresentadas por uma perspectiva de formação de leitores que leva em conta o letramento digital. Questões como essas, que permeiam a realidade dos jovens, devem ser expandidas até 
as salas de aula, promovendo reflexões acima disso. Rojo (1998, p. 181-182) contribui neste pensamento quando afirma que:

O letramento está também presente na oralidade, uma vez que, em sociedades tecnológicas como a nossa, o impacto da escrita é de largo alcance: uma atividade que evolve apenas a modalidade oral, como escutar notícias de rádio, é um evento de letramento, pois o texto ouvido tem as marcas de planejamento e lexicalização típicas da modalidade escrita.

Essas novas formas de ler presentes em sala de aula conduzem a pensar em outra forma de letramento que se faz importante neste estudo. Os desafios de leitura, no que tange à formação de leitores em uma perspectiva que se centra no letramento digital e na exploração de ferramentas digitais para práticas leitoras, devem estar baseados em alguns pressupostos, entre os quais: a) estímulo ao prazer da leitura do texto, com oportunidade de conhecer diversos gêneros, e não ênfase na leitura como atividade enfadonha e obrigatória; b) análise dos aspectos estruturais e estéticos do texto, assim como dos conteudísticos, numa associação entre forma e conteúdo; c) possibilidade de cotejo entre um texto e outros, de natureza literária ou não; d) associação entre o texto e vida social como forma de reconhecer os diálogos que um texto empreende com os contextos nos quais está inserida; e) recusa ao método tradicional de leituraexercícios e ao encaixe prioritário ou exclusivo de textos a meras classificações descritivas que pouco contribuem para compreender intencionalidades, formas de construção, inferências; f) a mediação de leitura realizada por professores que gostam de ler e que vejam o texto como um objeto rico para a formação dos alunos.

Considerando esses pressupostos, que possibilidades podem ser encontradas na rede, que sejam acessíveis e gratuitas, para estimular a construção de jogos on-line de leitura? Que reflexões podem ser construídas acerca de jogos digitais para a formação de leitores na educação básica, tomando-se como referência os objetivos da BNCC associados à leitura? A fim de elucidar essas discussões, apresentam-se algumas considerações sobre os alguns recursos digitais que permitem uma construção de jogos para contemplar competências e habilidades relacionadas à leitura. Para tanto, apresentam-se duas ferramentas: ELO e WORDWALL.

\section{PRÁTICAS LEITORAS ATRAVÉS DE JOGOS DIGITAIS: POTENCIALIDADES DAS PLATAFORMAS ELO E WORDWALL}

Para conhecer ferramentas das plataformas ELO e WORDWALL, apresentam-se suas caracterizações. Inicia-se com a plataforma ELO, que pode ser acessada pelo seguinte link: https://elo.pro.br/cloud/. Ela oferece potencialidades a duas esferas educativas: a criação de 
materiais por parte dos professores por meio da coautoria e de licenças abertas - 0 que se relaciona diretamente a característica e organização dessa plataforma - e, por outro lado, aos estudantes, oferece 0 acesso a módulos e atividades interativas, com a presença de recursos multisemióticos e multimodais que se distanciam dos materiais didáticos convencionais.

Esses dois aspectos citados serão melhor discorridos na sequência, pois justificam e fundamentam as potencialidades dessa ferramenta para a promoção de práticas de formação leitora no ensino fundamental. Diante da etapa formativa destacada, considera-se ainda a realidade atual da cibercultura que demanda novos recursos para a mediação do ensino e para 0 desenvolvimento de habilidade e o novo perfil do estudante que transita o espaço escolar, que se destaca pela necessidade de interação, de mobilidade e da instantaneidade para com suas ações.

A primeira esfera citada diz respeito à possibilidade de a plataforma ELO em oportunizar a criação de materiais por parte dos professores por meio da coautoria e de licenças abertas. Isso se deve ao fato de que a plataforma é considerada um Sistema de Autoria Aberto (BEVILÁQUA; COSTA; FIALHO, 2020) voltada para o ensino de línguas, assim como sigla ELO já destaca - Ensino de Línguas Online. Sendo um Sistema de Autoria Aberto, a plataforma ELO permite a criação de atividades diversas sobre quaisquer assuntos que não se limitam apenas à esfera de ensino de línguas, mesmo que tenha sido criado para esse fim, mas também possibilita a adaptação das atividades para de qualificação e formação leitora, por exemplo, que é o campo em que este trabalho possui enfoque.

Ainda, são possíveis, a partir da plataforma de autoria, as práticas de adaptação, reelaboração e edição de atividades já existentes, tendo em vista que todas as atividades criadas são armazenadas automaticamente e licenciadas no momento de criação sob licença Creative Commons BY - NC, nos quais garante o uso e a adaptação do material por terceiros desde que esses atribuam créditos ao autor e não utilizem os materiais para fins comerciais. Nesse sentido, professores/usuários podem interagir entre si contribuindo para a qualificação de materiais já existentes e disponíveis na plataforma, prática que leva a pensar no segundo aspecto citado que é o acesso a módulos e atividades interativas por parte dos alunos.

Através da prática de (co)autoria, os materiais tendem a ser cada vez mais atualizados, completos e coerentes com 0 que se propõem a desenvolver, o que acarreta no compartilhamento gratuito e de fácil acesso a materiais didáticos de qualidade que auxiliam de forma lúdica, desafiadora e atrativa o desenvolvimento de habilidades e competências importantes para a formação do estudante, sobretudo, em nível de leitura e de domínio crítico 
das tecnologias digitais. Como forma de melhor compreender a plataforma ELO, a organização e o rol de atividades que podem ser criadas, na sequência serão expostas algumas considerações a respeito do seu funcionamento.

Primeiramente, a plataforma possibilita três formas para acesso que se diferem de acordo com o que cada uma objetiva, dentre elas destacam-se o acesso como visitante, estudante e professor:

a) Visitante: forma de ingresso para aqueles/as que desejam ter apenas uma visão geral quanto às possibilidades do sistema, sem necessidade de cadastro; b) Estudante: forma de ingresso para aqueles/as que desejam buscar REA disponíveis no banco de atividades do ELO, com opção de cadastro, permitindo que o/a educador/a acompanhe seu desenvolvimento; $c$ ) Professor: forma de ingresso para aqueles/as que desejam produzir e/ou adaptar REA, criar cursos, acompanhar a aprendizagem dos/as educandos/as, entre outras possibilidades. (BEVILÁQUA; COSTA; FIALHO, 2020, p. 12)

Para a exposição e explanação das atividades existentes e as possibilidades dessas para a qualificação da formação leitora através desta plataforma, toma-se como exemplo 0 acesso a plataforma a partir da opção de estudante, pois dessa forma serão expostas as informações a partir do olhar dos estudantes, que são o público alvo desta pesquisa. Dessa forma, após o acesso como estudante, tem-se a possibilidade de aplicar descritores para efetivar uma busca no repositório de atividades da plataforma, espaço em que todas as atividades já criadas ficam armazenadas.

Figura 1 - Repositório de atividades do ELO

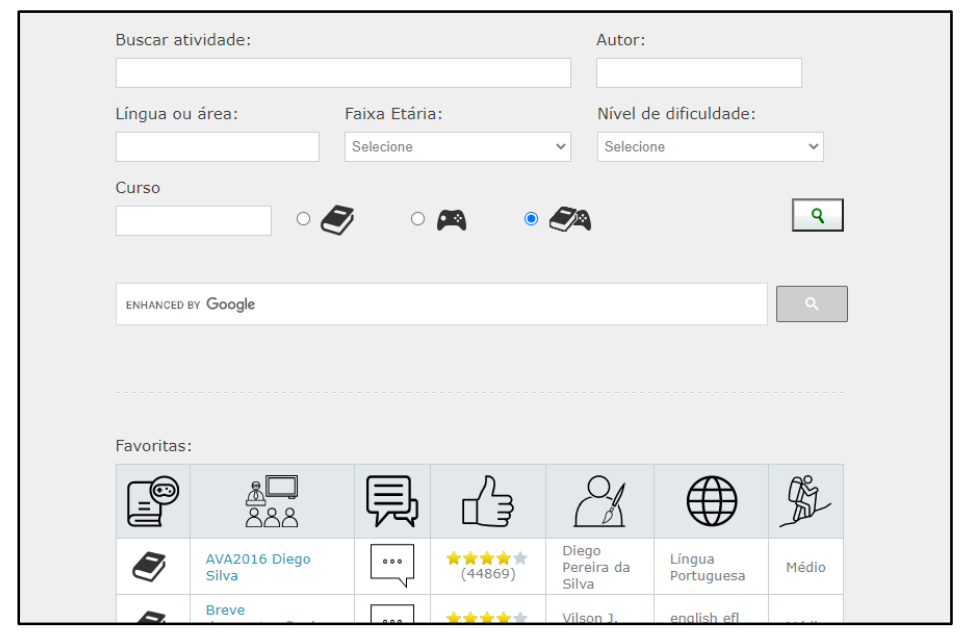

Fonte: ELO - Ensino de Línguas Online. Disponível em: https://elo.pro.br/cloud/aluno/busca- 
Na figura 1 é possivel observar os descritores que podem ser destacados para que a busca seja efetivada, dentre eles o nome da atividade, o nome do autor, a língua ou a área em que a atividade está associada, a faixa etária, o nível de dificuldade, se há algum curso em que a atividade foi desenvolvida e, por fim, o tipo da atividade que pode ser gamificada ou a partir da junção de módulos. A plataforma ELO dispõem de nove tipos de módulos, sendo eles: de memória, organizador, sequência, texto, eclipse, cloze, quiz, composer e vídeo. Alguns desses se assemelham a jogos já existentes mesmo não tendo a organização estética em forma de games como a versão gamificada que contabiliza a pontuação, o ranking e os desafios vencidos.

Nesse sentido, as especificidades de cada módulo citado possibilitam a criação de diversas atividades voltadas a promoção de leitura de forma livre, autoral e personalizada pelo professor. Cada atividade pode ser criada a partir da junção de vários módulos, o que permite a interação ativa do estudante a partir de recursos que necessitam da ação instantânea para dar seguimento a um novo módulo até que a atividade chegue ao fim. Ainda, no que diz respeito aos conteúdos, dependendo do módulo escolhido, podem ser inseridas informações, recursos visuais ou de vídeo que contribuem para o aumento da ludicidade e da sedução do estudante para com o material, assim como qualifica a própria atividade, a partir da perspectiva de que é possível desenvolver a leitura crítica diante de diversos gêneros ou recursos dispostos em um só material didático.

A proposta de leitura crítica a partir de diferentes recursos e em um sentido mais amplo se associa a proposta de leitura apresentada na BNCC (2017, p 72) na etapa formativa do ensino fundamental, que segundo o documento "diz respeito não somente ao texto escrito, mas também a imagens estáticas (foto, pintura, desenho, esquema, gráfico, diagrama) ou em movimento (filmes, vídeos etc.) e ao som (música), que acompanha e cossignifica em muitos gêneros digitais". Diante disso, na sequência serão apresentados alguns módulos que compõem atividades mais amplas, mas que exemplificam algumas das possibilidades da ferramenta ELO quando utilizada para a formação de leitores críticos e também para a promoção de práticas de letramento digital.

O primeiro módulo é o da memória que abarca, como o nome já destaca, um jogo de memória que pode ser formado de diferentes formas, seja somente a utilização de escrita, de imagens, ou de forma híbrida, o que proporciona uma prática interativa para com o estudante e 0 faz refletir sobre os aspectos em questão. No exemplo da figura 2 o jogo da memória está formado apenas por escrita e solicita que os estudantes correlacionem os livros com seus devidos personagens. Esse módulo pode ser utilizado como uma atividade pré-leitura ou como 
forma de testar os conhecimentos assimilados durante as reflexões estabelecidas em aula, pois possibilita o exercício da atenção e do estabelecimento de associações entre informações, ou imagens. Assim como os demais módulos, esse recurso de jogo da memória contribui também para a promoção da ludicidade e do envolvimento entre leitor e texto, principalmente pela composição de cores e pelo desafio encontrar os pares para seguir para o próximo módulo, caso houver.

Figura 2 - ELO na visão do estudante (Módulo Memória)

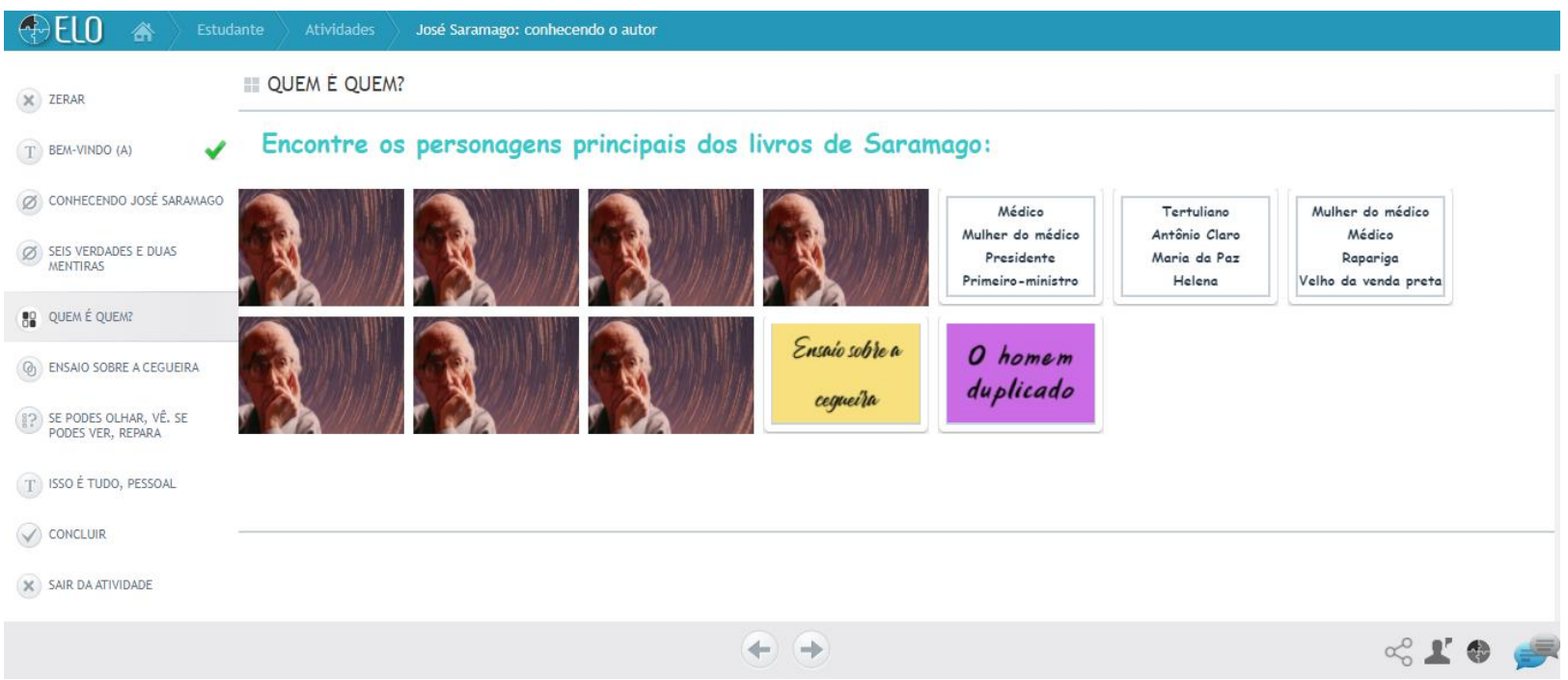

Fonte: ELO. Atividade criada por Marieli Theisen. Disponível em: https://elo.pro.br/cloud/aluno/ativ idade.php?id=6315\&etapa=3. Acesso em: 9 jul. 2021.

O segundo módulo é o cloze, que possibilita a criação de exercícios de verdadeiro e falso, enumeração ou ainda a inserção de lacunas em partes específicas do texto para que 0 estudante complete a partir da escuta de algum outro material, seja um vídeo ou música, ou a partir da leitura de poemas e demais textos. A figura 3 apresenta um exemplo de módulo cloze do tipo verdadeiro e falso que faz alusão a uma temática como forma de testar, assim como 0 jogo da memória, os conhecimentos do aluno a respeito desta. Esse módulo possibilita a criação de diversos exercícios sobre objetos de leitura diversos, que podem ser aprofundados em nível de compreensão, de interpretação, de estrutura e conteúdo e sobretudo, promovendo a reflexão crítica do leitor. É importante destacar que é possível inserir nesse módulo recursos de vídeo ou imagens, assim como o exemplo abaixo: 
Figura 3 - ELO na visão do estudante (Módulo Cloze)

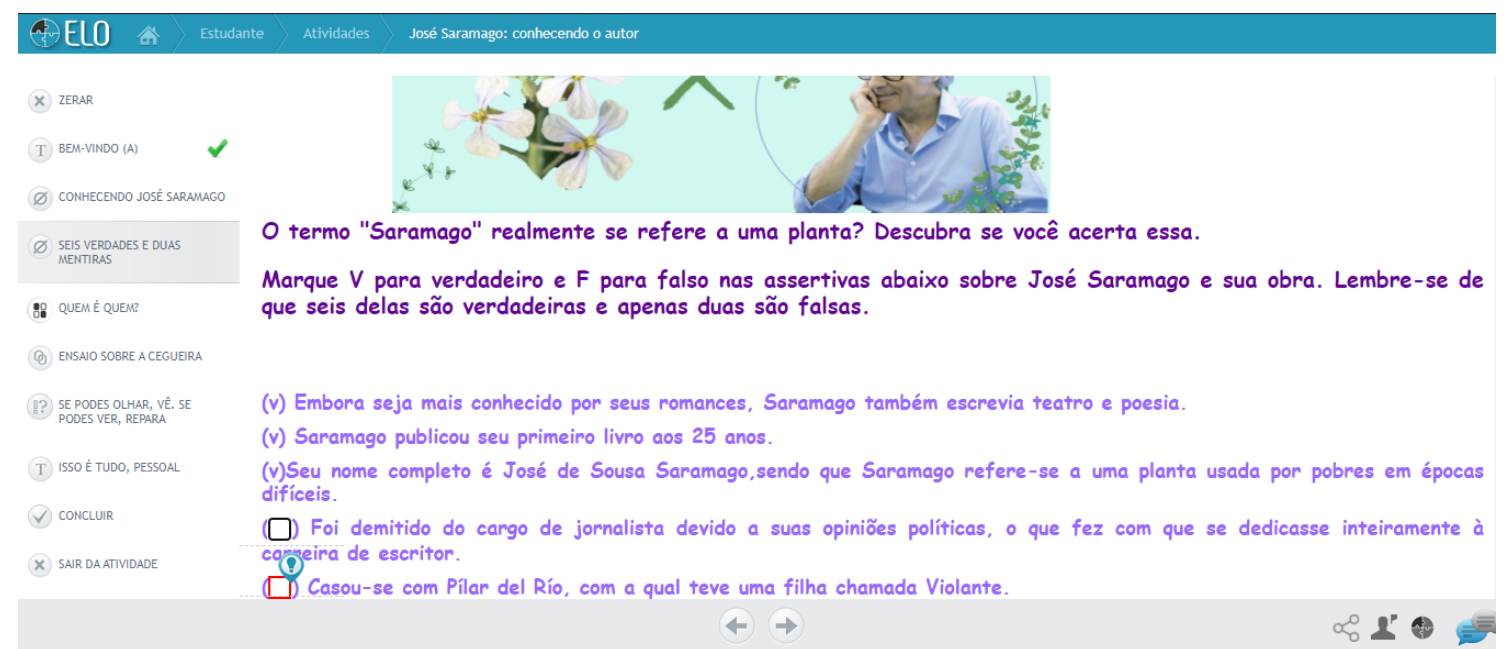

Fonte: ELO. Atividade criada por Marieli Theisen. Disponível em: https://elo.pro.br/cloud/aluno/atividade .php?id=6315\&etapa=2. Acesso em: 3 jul. 2021.

O terceiro a ser destacado é o módulo sequência, pois esse possibilita a prática de ordenação de sentenças que geralmente são apresentadas de forma contextualizada a partir de músicas, vídeos ou demais informações expostas na página. 0 módulo sequência desenvolve a compreensão do leitor por meio da leitura atenta e do desafio de ordenar de forma correta as informações dadas. Como exposto na figura 4, esse módulo também permite a inserção de outros recursos audiovisuais que auxiliam na ordenação e na expansão de possibilidades a serem desenvolvidas. Com essa proposta de atividade o estudante é posto em contato com os objetos de leitura de forma mais atenta, tendo em vista que após a leitura ele é desafiado a rememorar aspectos da leitura de forma organizada e sequencial.

Figura 4 - ELO na visão do estudante (Módulo Sequência)

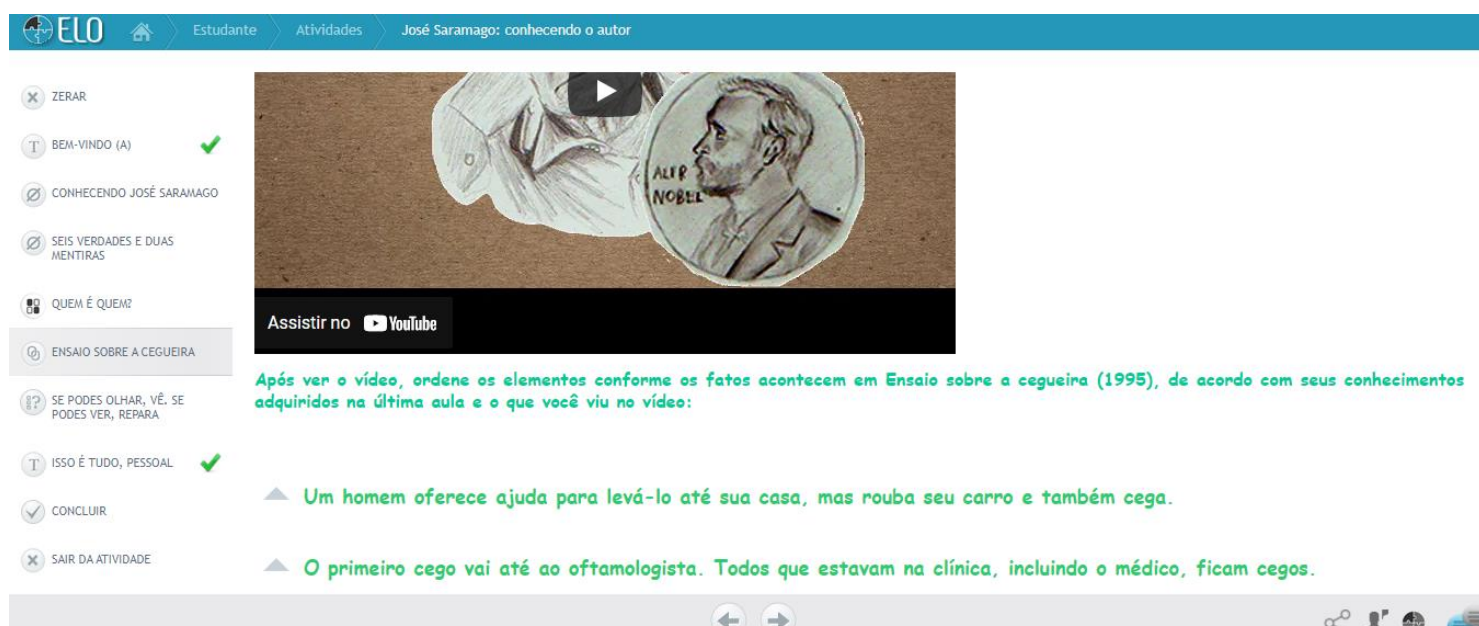


Por fim, o módulo quiz permite a criação de questões diversas que podem ser de múltipla escolha ou também discursivas pautadas em vídeos, imagens, textos ou apenas revisando materiais já estudados. Esse módulo permite uma exploração ampla de quaisquer tipos de objetos de leitura e com diferentes enfoques, sendo esses mais reflexivos e interpretativos por meio de respostas discursivas ou mais objetivos através de questões de múltipla escolha. No exemplo da figura 5, o módulo quiz é composto por questões de múltipla escolha apenas, mas que possibilitam a explanação da obra literária em questão com

Fonte: ELO. Atividade criada por Marieli Theisen. Disponível em: https://elo.pro.br/cloud/aluno/atividade.ph p?id=6315\&etapa=4. Acesso em: 3 jul. 2021.

Figura 5 - ELO na visão do estudante (Módulo Quiz)

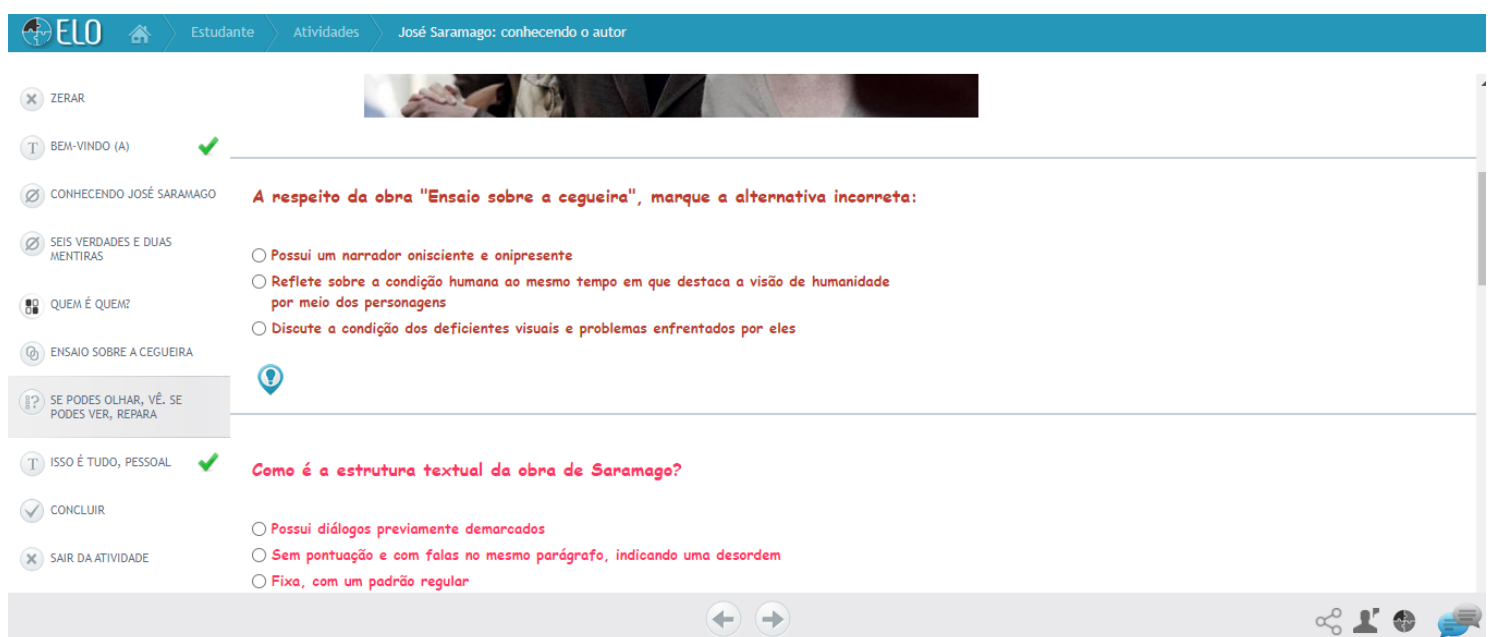

Após a exposição de quatro tipos de módulos que compõem a plataforma ELO, concluise que todos oferecem o contato com propostas interativas que exigem do aluno atenção e ação assim como em jogos. Os módulos podem ser editados de forma colorida e atrativa com uso de imagens e ainda todas as atividades oferecem ao estudante o feedback de suas respostas de forma instantânea, o que auxilia no processo de aprendizagem e na observação dos aspectos que ainda precisam ser revisados. Através da articulação de texto, vídeos, imagens, cores e

Fonte: ELO. Atividade criada por Marieli Theisen. Disponível em: https://elo.pro.br/cloud/aluno/atividade.php ?id=6315\&etapa=5. Acesso em: 20 jul. 2021.

exigem novas formas de comportamento, interação e ação. 
Na sequência, visando a promover a integração das tecnologias digitais e a vasta gama de possibilidades disponibilizadas pelas mesmas e potencializar o processo de ensinoaprendizagem pela ótica dos multiletramentos e no intuito de englobar o processo de leitura e compreensão de maneira interativa, centra-se a exposição sobre plataforma digital WORDWALL, cujo acesso é possível no link https://wordwall.net/pt . Ela oferece várias possibilidades de jogos lúdicos que estimulam a alfabetização e o letramento digital, proporcionando, através de suas atividades personalizadas, o desenvolvimento e habilidades e competências necessárias para que o aluno torne-se um leitor fluente de sua língua (e outras línguas nacionais e internacionais), crítico e reflexivo do saber fazer ofertado pela multissemiose promovida pela cibercultura.

Wordwall é uma plataforma versátil, com a intencionalidade de criar atividades diferenciadas, em modelo gamificado, o que exige que o jogador se integre do jogo e faça a leitura de todas as estratégias do mesmo, dependendo do tipo de jogo escolhido na hora da criação. Também há diversas atividades que ao serem criadas podem ser utilizadas em várias disciplinas, de maneira interdisciplinar, multimodal e em diversas linguagens. Pode-se realizar a inscrição no site da plataforma ou até mesmo logar com a conta google, porém, mesmo antes do login, é possível ter acesso a página inicial, esta que oportuniza diversas atividades já criadas por outros usuários do WORDWALL, deste jeito mostra uma visão geral das possibilidades de aplicação linguísticas-multimodais contidas na plataforma.

A plataforma difere-se em dois modos: o gratuito e o pro. 0 primeiro módulo disponibiliza ao usuário a criação de cinco atividades diferentes, as mesmas podem ser editadas pelo professor/usuário livremente, porém não há possibilidade de criar novas atividades/jogos além da quantidade ofertada. $\mathrm{O}$ segundo modo: pro, tem custo, porém tem vários benefícios pois, de maneira ilimitada cria e armazena atividades. 0 usuário, assim que estiver logado na plataforma, pode clicar em "criar atividade" para construir seu primeiro jogo on-line. Uma das vantagens de utilização desta plataforma é que as atividades on-line desenvolvidas através de jogos podem ser impressas, dependendo os recursos tecnológicos ofertados pela escola, também há essa possibilidade de qualificar a prática docente. Destaca-se que para o uso dos jogos da plataforma necessita que os usuários estejam conectados com a internet, não tem a possibilidade de instalar nos aparelhos móveis ou computadores, apenas acesso na plataforma.

Na sequência, faz-se uma breve apresentação da plataforma com o viés de fomentar seu uso nas atividades práticas da vida docente. Esta apresentação dar-se-á no modo gratuito e sem login do usuário, apenas com as atividades disponibilizadas na página inicial. 


\section{W Wordwall \\ A maneira mais fácil de criar seus próprios recursos didáticos.}

Inicio Recursos Planos De Preços

Iniciar Sessão Inscrever-se

Português

Prepare atividades personalizadas para sua sala de aula.

Questionários, competições, jogos de palavras e muito mais.

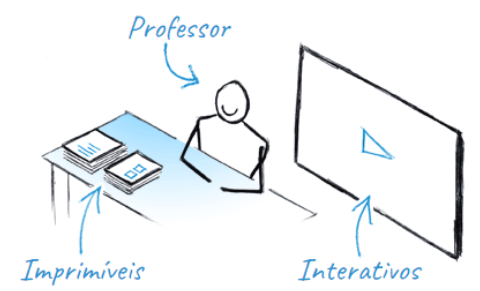

19.289.313 recursos criados

Inscreva-se para começar a criar

Fonte: WORDWALL. Disponível em: https://wordwall.net/pt. Acesso em: 20 de jul. 2021.

Figura 2- Passo a passo da utilização da plataforma

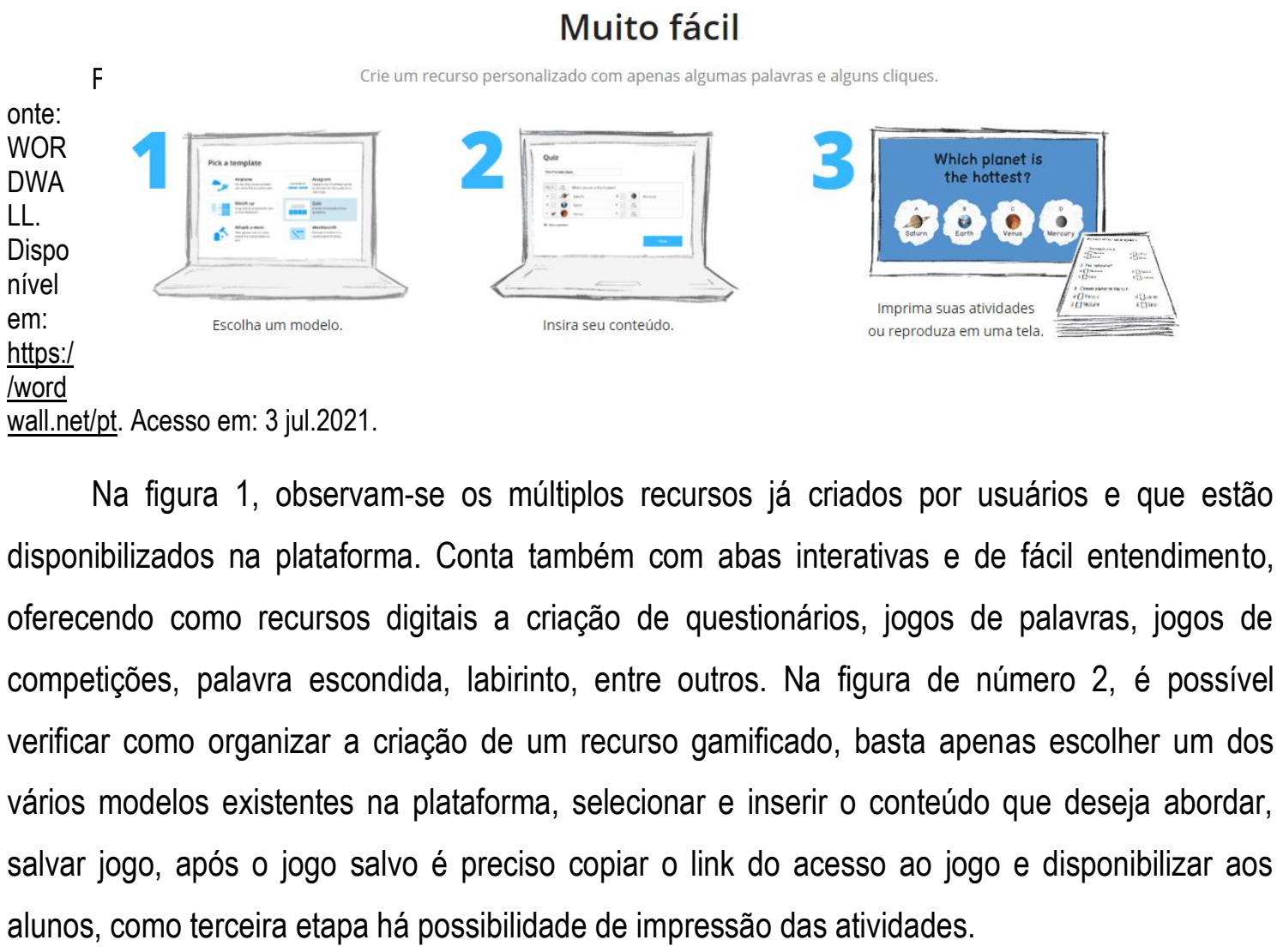




\section{Saiba mais sobre nossos modelos}

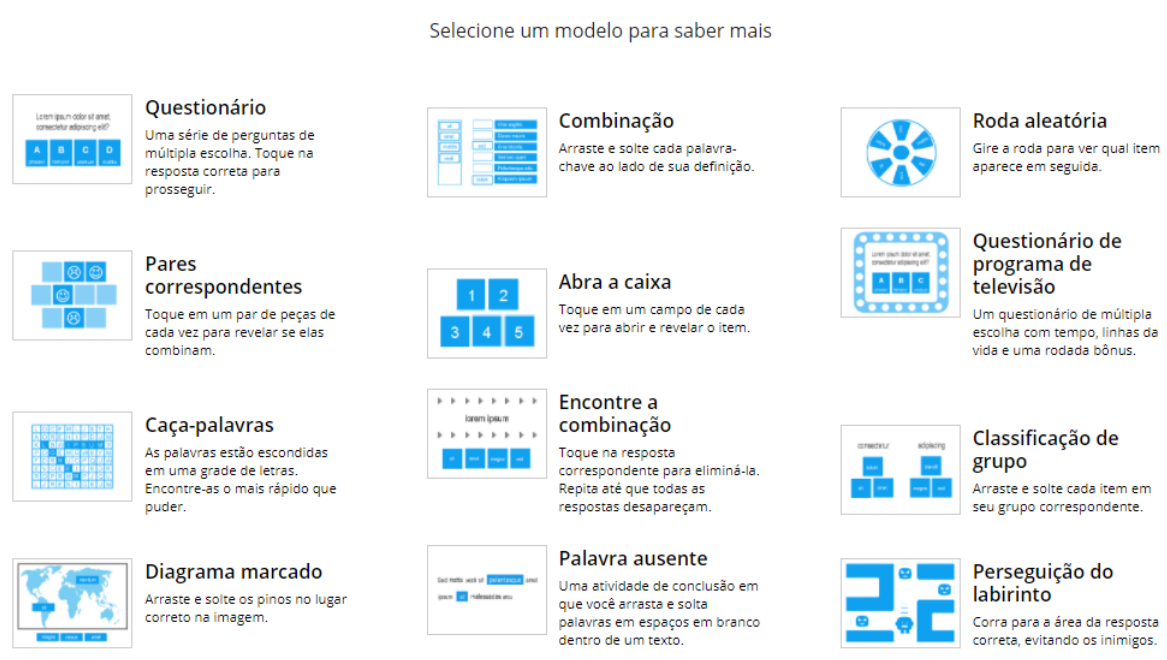

Figura 3- Modelos de Atividades Gamificadas

Fonte: WORDWALL. Disponivel em: https://wordwall.net/pt. Acesso em: 20 jul. 2021.

Figura 4- continuação da figura 3
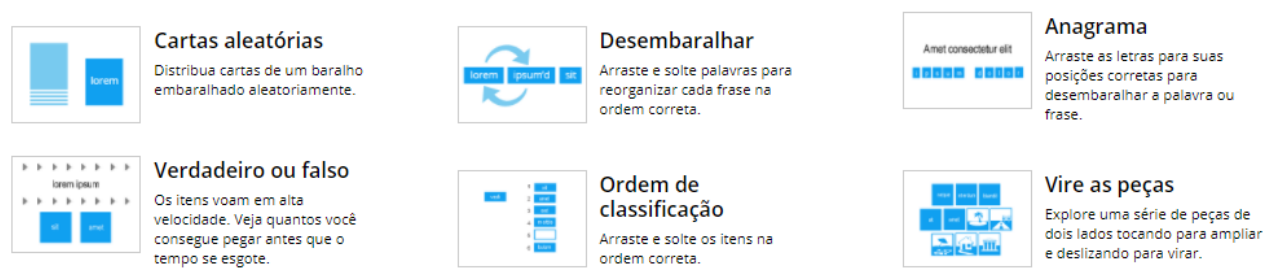

Inscreva-se para começar a criar

Fonte: WORDWALL. Disponivel em: https://wordwall.net/pt. Acesso em: 20 jul. 2021.

As imagens 3 e 4 mostram as possibilidades de atividades gamificadas ofertadas pela plataforma. Para criar os jogos, é preciso inscrever-se (caso não tenha feito o cadastro) ou fazer o login, após escolher uma modalidade de atividade que vise a estimulação das habilidades e competências que necessitam serem desenvolvidas no processo de alfabetização e letramento pessoal, social e digital dos alunos nascidos na era da cibercultura. Assim sendo, a BNCC (2018) contempla ao que diz respeito ao desenvolvimento de habilidades de leitura e escrita "a fim de garantir amplas oportunidades para que os alunos se apropriem do sistema de escrita alfabética de modo articulado ao desenvolvimento de outras habilidades de leitura e de escrita e ao seu envolvimento em práticas diversificadas de letramentos". 
Face a apresentação da plataforma, escolhemos algumas atividades já organizadas e produzidas por outros professores/usuários, afim de fomentar o uso de tecnologias digitais para desenvolver as habilidades e competências ao que tange o letramento e alfabetização dos alunos. As atividades gamificadas foram selecionadas contemplam o modo gratuito e visa a estimulação do viés tecnológico na prática docente. Oferecendo aos alunos a ampliação da "autonomia intelectual, a compreensão de normas e os interesses pela vida social, o que thes possibilita lidar com sistemas mais amplos, que dizem respeito às relações dos sujeitos entre si, com a natureza, com a história, com a cultura, com as tecnologias e com o ambiente." (BNCC, 2018, p.59)

Figura 5- Exemplo de Atividade- Caça-palavras envolvendo o jogo "Minecraft" com nomes de animais

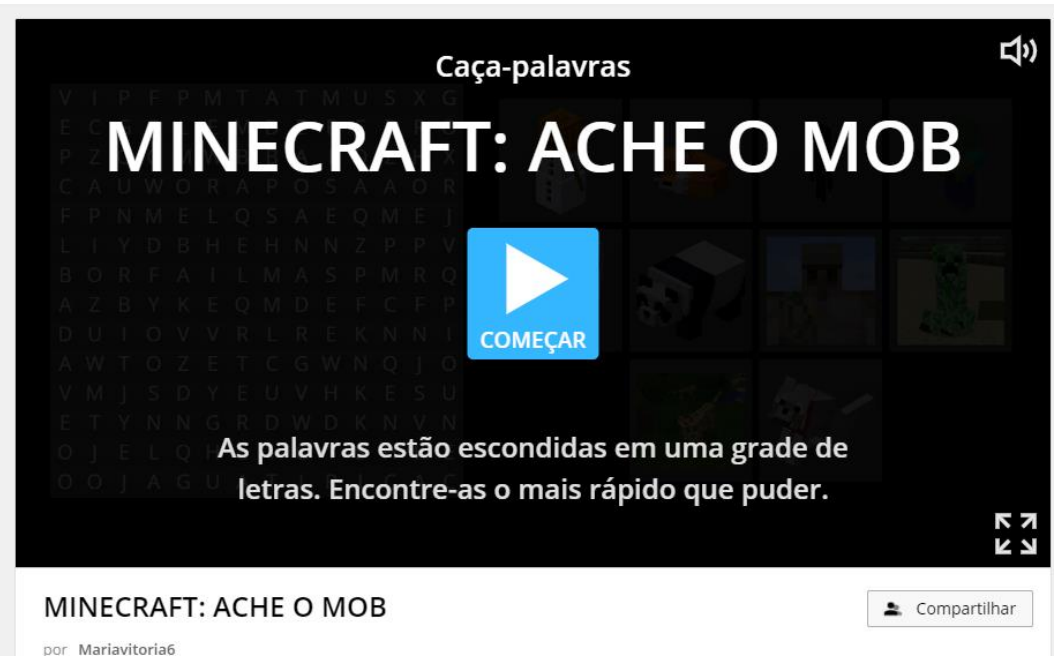

Fonte: WORDWALL. Criado por: Mariavitoria6. Disponível em: <https://wordwall.net/pt/resource/11857554/minecraft-ache-o-mob>. Acesso em: 2 jul. 2021.

Figura 6- Continuação da atividade anterior;

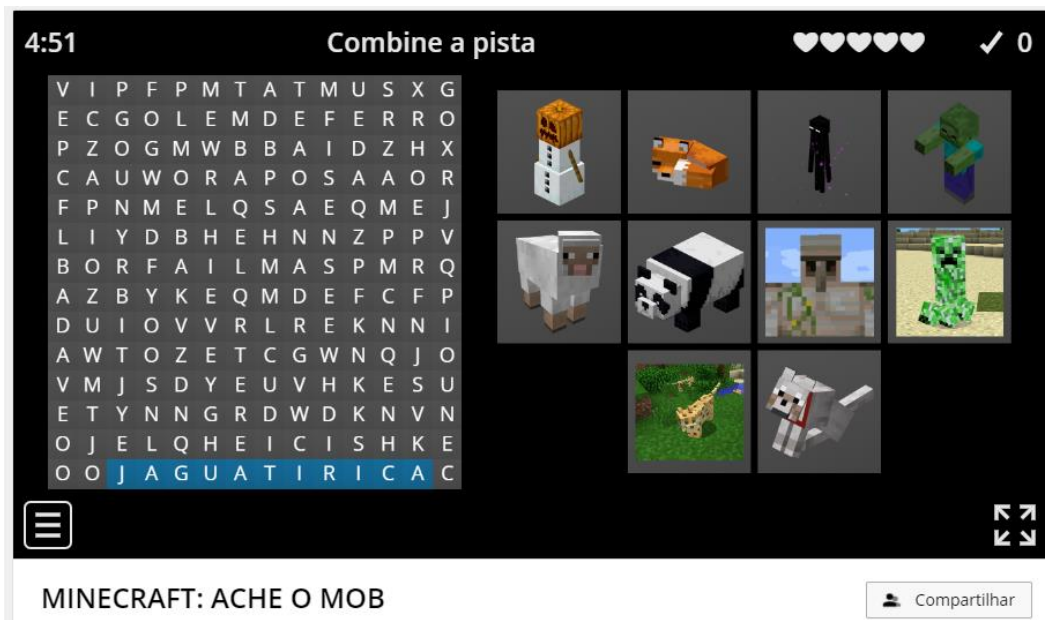

Revista de Ciências Humanas, Frederico Westphalen - RS, v. 22, n.2, p. 45-68, maio/ago. 2021. Recebido em: 20/05/2021 Aceito em: 21/06/2021 
Fonte: WORDWALL. Criado por: Mariavitoria6. Disponivel em: <https://wordwall.net/pt/resource/11857554/minecraft-ache-o-mob>. Acesso em: 2 jul. 2021.

Nesta atividade é possível visualizar a intenção de trazer para a aula o contexto vivido pelos alunos, diante de um jogo comum para os nascidos digitais é viável a produção de conhecimento. Através das imagens de animais, produzidas no "mundo" do Minecraft pode-se trabalhar a leitura dos nomes dos animais. Esta atividade gamificada tem temporizador o que estimula a leitura e raciocínio rápido dos alunos.

Figura 7- Atividade: Palavra ausente- Encontre a Rima e complete o poema

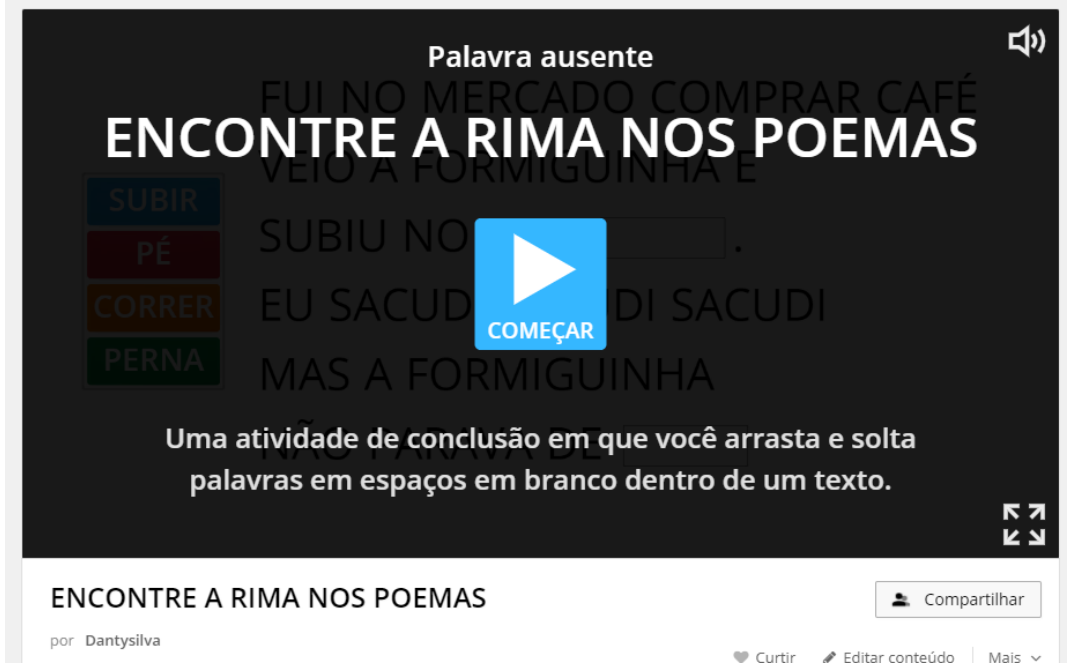

Fonte: WORDWALL. Criado por Dantysilva. Disponível em: <

https://wordwall.net/pt/resource/11731428/treino-de-leitura/encontre-rima-nos-poemas>. Acesso em: 2 jul. 2021.

Figura 8- Sequência da atividade da figura 7 


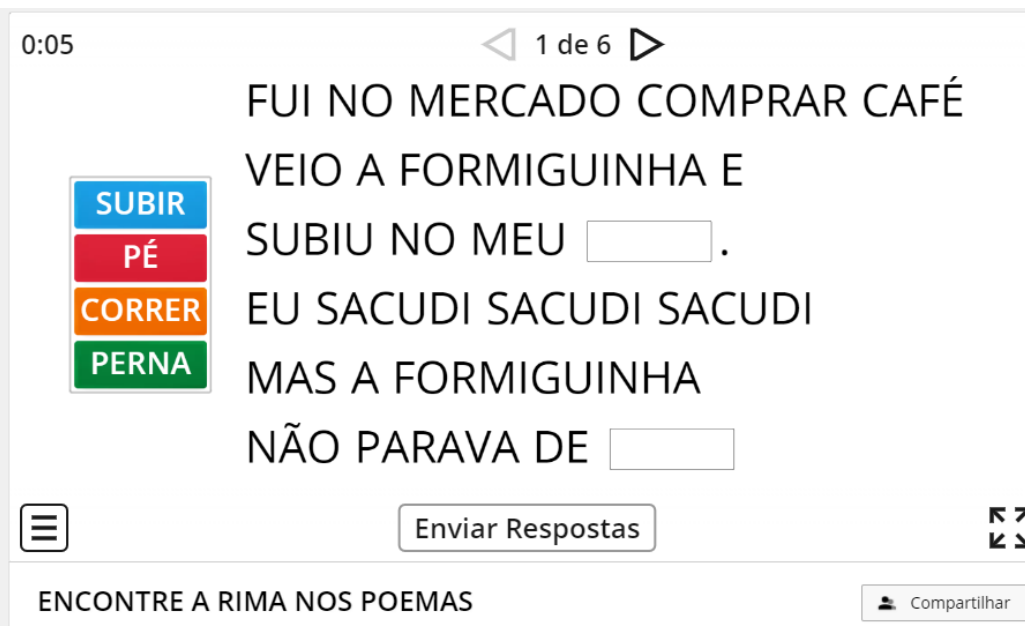

Fonte: WORDWALL. Criado por Dantysilva. Disponível em:

<https://wordwall.net/pt/resource/11731428/treino-de-leitura/encontre-rima-nos-poemas>. Acesso em: 20 jul. 2021.

As ilustrações 7 e 8 sugerem uma atividade de completar o poema com a rima que está faltando. É um importante recurso para trabalhar a leitura e a compreensão de textos, bem como explorar os sons produzidos pelas rimas ao final de cada verso do poema ou música. As rimas são ótimas para trabalhar a memorização e consciência fonológica das crianças. Diante disso, Oliveira (2021) destaca que "praticar textos rimados em voz alta é divertido e colabora para que as crianças entendam melhor os significados das palavras. $E$ isso permite uma compreensão mais ampla da linguagem e da Língua Portuguesa." Dessa forma, as rimas aliadas aos jogos disponibilizados pela plataforma WORDWALL tornam o processo de alfabetização e letramento mais interessante, com muito mais sentido e significado.

A criação e a aplicação de novas metodologias em sala de aula favorecem a aprendizagem e a leitura de diversas linguagens contidas no processo de alfabetização. Os recursos tecnológicos disponíveis na cibercultura estimula a criatividade, participação, interesse e motivação dos alunos, favorecendo a construção de novos saberes, aproximando professor e aluno na dinâmica constante de aprender a aprender. Conforme Zaluski e Oliveira (2018) a elaboração da educação com jogos desperta o interesse do aluno em aprender e a perceber a importância do que aprende no cotidiano tornando o ensino significativo e transformador.

Após a ilustração de algumas atividades voltadas à promoção de práticas leitoras com uso das plataformas ELO e WORDWALL para etapa do ensino fundamental, pode-se apresentar uma síntese de algumas análises sobre esses recursos, conforme exposto no quadro a seguir, no qual estão reunidos alguns critérios de observação que visam a mostrar potencialidades e limitações das ferramentas. 


\begin{tabular}{|c|c|c|c|c|}
\hline \multirow[t]{2}{*}{ Critério de análise } & \multicolumn{2}{|c|}{ Potencialidades } & \multicolumn{2}{|c|}{ Limitações } \\
\hline & ELO & WORDWALL & ELO & WORDWALL \\
\hline $\begin{array}{l}\text { Acesso aos } \\
\text { recursos }\end{array}$ & $\begin{array}{l}\text { Livre, gratuito, } \\
\text { reutilizável e } \\
\text { ilimitado, com opção } \\
\text { de definir nível de } \\
\text { dificuldade, público- } \\
\text { alvo, temas-chave }\end{array}$ & $\begin{array}{l}\text { Livre ou paga, } \\
\text { sendo esta com } \\
\text { mais ferramentas }\end{array}$ & $\begin{array}{l}\text { Limita-se ao uso } \\
\text { das ferramentas } \\
\text { disponibilizadas } \\
\text { para edição }\end{array}$ & $\begin{array}{l}\text { Limita-se ao uso } \\
\text { das ferramentas } \\
\text { disponibilizadas } \\
\text { para edição. } \\
\text { A versão gratuita } \\
\text { limita-se à } \\
\text { construção de } 5 \\
\text { atividades. } \\
\text { As versões dos } \\
\text { pacotes pagos são } \\
\text { mais completas e de } \\
\text { uso mais amplo }\end{array}$ \\
\hline $\begin{array}{l}\text { Manuseio as } \\
\text { plataformas }\end{array}$ & $\begin{array}{l}\text { Fácil, exigindo uma } \\
\text { conta para o } \\
\text { usuário. } \\
\text { Atividades podem } \\
\text { ser enviadas pelo } \\
\text { link gerado }\end{array}$ & $\begin{array}{l}\text { Fácil, exigindo uma } \\
\text { conta para o } \\
\text { usuário. Atividades } \\
\text { podem ser enviadas } \\
\text { pelo link gerado }\end{array}$ & $\begin{array}{l}\text { Embora não seja } \\
\text { complexo o } \\
\text { manuseio, exige dos } \\
\text { professores certa } \\
\text { familiaridade } \\
\text { tecnológica para } \\
\text { formatação das } \\
\text { atividades para que } \\
\text { estas fiquem } \\
\text { visualmente } \\
\text { atrativas }\end{array}$ & $\begin{array}{l}\text { Embora não seja } \\
\text { complexo o } \\
\text { manuseio, os } \\
\text { layouts são prontos, } \\
\text { restringindo a } \\
\text { criação visual de } \\
\text { forma mais autoral }\end{array}$ \\
\hline $\begin{array}{l}\text { Diversificação de } \\
\text { atividades a serem } \\
\text { criadas }\end{array}$ & $\begin{array}{l}\text { Muito boa no } \\
\text { sentido de } \\
\text { proporcionar } \\
\text { interação, } \\
\text { criatividade e } \\
\text { amplas } \\
\text { possibilidades de } \\
\text { exploração das } \\
\text { ferramentas }\end{array}$ & $\begin{array}{l}\text { Muito boa no } \\
\text { sentido de } \\
\text { proporcionar } \\
\text { interação, } \\
\text { criatividade e } \\
\text { amplas } \\
\text { possibilidades de } \\
\text { exploração das } \\
\text { ferramentas }\end{array}$ & $\begin{array}{l}\text { São disponíveis } 9 \\
\text { ferramentas } \\
\text { diferentes, o que } \\
\text { não permite criação } \\
\text { de qualquer } \\
\text { atividade, apenas as } \\
\text { que as ferramentas } \\
\text { suportam }\end{array}$ & $\begin{array}{l}\text { São disponíveis } 8 \\
\text { ferramentas } \\
\text { diferentes, o que } \\
\text { não permite criação } \\
\text { de qualquer } \\
\text { atividade, apenas as } \\
\text { que as ferramentas } \\
\text { Maior diversificação } \\
\text { está associada à } \\
\text { compra de pacotes }\end{array}$ \\
\hline $\begin{array}{l}\text { Ludicidade das } \\
\text { ferramentas }\end{array}$ & $\begin{array}{l}\text { Com a alternativa } \\
\text { de gamificação, } \\
\text { quando são } \\
\text { construídas mais de } \\
44 \text { atividades, a } \\
\text { ludicidade é maior }\end{array}$ & $\begin{array}{l}\text { Boa ludicidade } \\
\text { dependendo da } \\
\text { escolha das } \\
\text { modalidades da } \\
\text { plataforma }\end{array}$ & $\begin{array}{l}\text { Muito mais } \\
\text { associada à } \\
\text { criatividade do } \\
\text { professor na } \\
\text { construção das } \\
\text { atividades } \\
\end{array}$ & $\begin{array}{l}\text { Muito mais } \\
\text { associada à } \\
\text { criatividade do } \\
\text { professor na } \\
\text { construção das } \\
\text { atividades }\end{array}$ \\
\hline $\begin{array}{l}\text { Integração de } \\
\text { tecnologias digitais } \\
\text { na formação de } \\
\text { leitores }\end{array}$ & $\begin{array}{l}\text { Muito boa, } \\
\text { especialmente } \\
\text { porque permite a } \\
\text { integração de textos } \\
\text { de múltiplas } \\
\text { semioses para } \\
\text { desenvolvimento de } \\
\text { práticas de leitura }\end{array}$ & $\begin{array}{l}\text { Muito boa, } \\
\text { especialmente pela } \\
\text { facilidade de uso, } \\
\text { pela quantidade de } \\
\text { ferramentas }\end{array}$ & $\begin{array}{l}\text { Limita-se ao } \\
\text { domínio do criador } \\
\text { quanto ao uso das } \\
\text { ferramentas e à } \\
\text { criatividade na } \\
\text { construção de } \\
\text { atividades }\end{array}$ & $\begin{array}{l}\text { Limita-se ao } \\
\text { domínio do criador } \\
\text { quanto ao uso das } \\
\text { ferramentas e à } \\
\text { criatividade na } \\
\text { construção de } \\
\text { atividades }\end{array}$ \\
\hline Motivação da leitura & $\begin{array}{l}\text { Bom nível de } \\
\text { motivação dada a } \\
\text { facilidade de acesso } \\
\text { ao material por meio } \\
\text { digital e as } \\
\text { ferramentas } \\
\text { disponíveis, bem } \\
\text { como a } \\
\text { diferenciação com o } \\
\text { que se tem em }\end{array}$ & $\begin{array}{l}\text { Bom nível de } \\
\text { motivação dada a } \\
\text { facilidade de acesso } \\
\text { ao material por meio } \\
\text { digital e as } \\
\text { ferramentas } \\
\text { disponíveis, bem } \\
\text { como a } \\
\text { diferenciação com o } \\
\text { que se tem em }\end{array}$ & $\begin{array}{l}\text { A pouca criatividade } \\
\text { ou apenas a } \\
\text { substituição do } \\
\text { impresso pelo digital } \\
\text { na construção de } \\
\text { atividades pode ser } \\
\text { fator negativo para } \\
\text { uso da plataforma }\end{array}$ & $\begin{array}{l}\text { A pouca criatividade } \\
\text { ou apenas a } \\
\text { substituição do } \\
\text { impresso pelo digital } \\
\text { na construção de } \\
\text { atividades pode ser } \\
\text { fator negativo para } \\
\text { uso da plataforma }\end{array}$ \\
\hline
\end{tabular}




\begin{tabular}{|l|l|l|l|l|}
\hline & $\begin{array}{l}\text { manuais impressos, } \\
\text { por exemplo }\end{array}$ & $\begin{array}{l}\text { manuais impressos, } \\
\text { por exemplo }\end{array}$ & \\
\hline $\begin{array}{l}\text { Desenvolvimento de } \\
\text { competências e } \\
\text { habilidades de } \\
\text { leitura conforme } \\
\text { orientações da } \\
\text { BNCC }\end{array}$ & $\begin{array}{l}\text { Oárias fermentas, } \\
\text { todas distintas, e } \\
\text { que podem ser } \\
\text { associados à leitura } \\
\text { de diferentes textos } \\
\text { em uma mesma fermentas, } \\
\text { todas distintas, e } \\
\text { que podem ser } \\
\text { associados à leitura } \\
\text { de diferentes textos } \\
\text { gamificação }\end{array}$ & $\begin{array}{l}\text { Poucas ferramentas } \\
\text { para atividades com } \\
\text { questões abertas }\end{array}$ & $\begin{array}{l}\text { Prioridade para } \\
\text { atividades fechadas }\end{array}$ & \\
\hline $\begin{array}{l}\text { Aplicabilidade das } \\
\text { ferramentas no } \\
\text { ensino }\end{array}$ & Excelente & Excelente & $\begin{array}{l}\text { Sem acesso à rede, } \\
\text { não é possível usar } \\
\text { a plataforma }\end{array}$ & $\begin{array}{l}\text { Sem acesso à rede, } \\
\text { não é possível usar } \\
\text { a plataforma }\end{array}$ \\
\hline
\end{tabular}

Fonte: elaborado pelas autoras

\section{CONSIDERAÇÕES FINAIS}

A partir dessa análise dos recursos digitais que podem ser explorados para construção de atividades dos jogos de leitura, considerando-se as sugestões apresentadas, notam-se algumas potencialidades do uso de ferramentas digitais na promoção de leitura na educação básica. Dentre as potencialidades, ressalta-se primeiramente a interatividade do aluno com a tela de em equipamento que lhe dá acesso a outras possibilidades de ser um jogador não apenas com o foco no entretenimento, mas com possibilidades de ampliação de competências leitoras. A interatividade que as atividades propõem é fator importante de aproximação do aluno com 0 objeto de leitura, além de constituir uma forma motivadora de estimular a ler. Assim, a leitura não passar a ser vista como uma atividade obrigatória e enfadonha.

Cada um dos recursos expostos contempla opções diversificadas que valorização a atenção, a concentração e a ludicidade, o que se constitui em elementos importantes para explorar a leitura em contextos em que ela precisa ser ressignificada para ser mais interessante aos olhos das crianças. Com a exploração das plataformas ELO e WORDWALL, as atividades de leitura podem fugir bastante dos esquemas tradicionais de texto-leitura-exercícios-correção no sentido de oportunizarem novos mecanismos de leitura e apropriação de textos eleitos como objeto de discussão.

No entanto, é preciso pontuar que os recursos, embora sejam permeados de potencialidades para atividades de leitura, apresentam limitação no que tange a estudos de maior aprofundamento da prática de leitura. Isso se justifica, uma vez que, mesmo que possibilitem atividades de reflexão sobre os objetos de leitura sobre o qual são formadas as atividades, não são ferramentas completas. Questões como as que permitem uma reflexão mais 
longa, construída em parágrafos, por exemplo, não são viáveis nas ferramentas, o que implica uma dissociação da leitura da prática de produção textual sobre a leitura e as reflexões que esta suscita. Para Kleiman (2002, p. 26) nem todas as atividades, mesmo que diversificadas e focadas na participação do aluno, são capazes de formar leitores e acarretar uma aprendizagem significativa, pois

\begin{abstract}
Somente quando se ensina o aluno a perceber esse objeto que é o texto em toda sua beleza e complexidade, isto é, como ele está estruturado, como ele produz sentidos, quantos significados podem se aí sucessivamente revelados, ou seja, somente quando são mostrados ao aluno modos de se envolver com esse objeto, mobilizando os seus saberes, memórias, sentimentos para assim, compreendê-lo, há ensino de leitura.
\end{abstract}

Soma-se a esse fator 0 tipo de abordagem dos recursos centra-se em possibilidades para exploração de questões de múltipla escolha que aparecem repaginadas com as possibilidades de interação oferecidas pelas plataformas. Elas são importantes para a compreensão leitora, permitem diferentes construções, porém, para que essa modalidade seja bem explorada, há necessidade de o professor saber construir as questões, com diversidade de formato, com riqueza de detalhes, com criatividade. Além disso, é relevante destacar que a formação leitora não pode se restringir a esse tipo de atividade embora em situações de avaliação de larga escala esse tipo de questão seja dominante.

Outro ponto relevante para que as plataformas sejam um elemento agregador de competências leituras na escola refere-se ao desempenho de quem cria as atividades, 0 professor. A criatividade e inovação na forma de exploração os objetos de leitura continua sendo fator decisivo para o sucesso de uma prática pedagógica centrada na leitura, uma vez que as ferramentas digitais são apenas um aporte e não salvam nenhuma prática de um possível insucesso. Nesse sentido, é fundamental que o professor, além de conhecer as ferramentas de cada uma que o qualificam como um profissional com letramento digital, saiba explorá-las de forma adequada a cada etapa e objetivos de sua prática, seja criativo na construção das atividades e saiba motivar 0 aluno para 0 ato de ler.

Ainda é preciso pontuar que o uso de jogos interativos da internet surtirá efeito positivo no processo de formação de leitores se forem adaptados aos objetivos do ensino de leitura de cada contexto educacional e forem explorados por professores que saber motivar 0 aluno para a leitura e que gostam de ler, pois "o exemplo do professor, que revela uma ligação de afeto com o livro e com o universo nele contido, desvelado no ato de ler, constitui maior estímulo ao aluno" (ROSING, 1996, p. 22). 


\section{REFERÊNCIAS}

ALVES, Lynn. Relações entre os jogos digitais e aprendizagem: delineando percurso.

Educação, Formação \& Tecnologias, v.1(2); p. 3-10, nov. 2008. Disponível em:

http://www.lynn.pro.br/admin/files/lyn_artigo/6030abd204.pdf. Acesso em: 19 jul. 2021.

BURLAMAQUE, Fabiane Verardi. Os primeiros passos na constituição de leitores autônomos: a formação do professor. In: TURCHI, Maria Zaira; SILVA, Vera Maria Tietzmann (Orgs.). Leitor formado, leitor em formação: leitura literária em questão. São Paulo: Cultur Acadêmica; Assis, SP: ANEP, 2006. p. 79-91.

BRASIL. Ministério da Educação. Secretaria da Educação Básica. Base nacional comum curricular. Brasília, DF, 2017. Disponível em:

http://basenacionalcomum.mec.gov.br/images/BNCC_EI_EF_110518_versaofinal_si

te.pdf. Acesso em: 7 jul. 2021.

BRASIL. INEP. Relatório Brasil no PISA 2018. Disponível em:

https://download.inep.gov.br/acoes_internacionais/pisa/documentos/2019/relatorio_PISA_2018_p reliminar.pdf. Acesso em: 10 jun. 2021.

CHARTIER, Roger. Práticas da leitura. São Paulo: Estação Liberdade, 2009.

KLEIMAN, Angela. Contribuições teóricas para o desenvolvimento do leitor: teorias de leitura e ensino. In: ROSING, Tania Mariza Kuchenbecker; BECKER, Paulo Ricardo (Orgs.). Leitura e animação cultural: repensando a escola e a biblioteca. Passo Fundo: UPF, 2002. p. 25-45.

INSTUTUTO PRÓ-LIVRO. Retratos da leitura no Brasil - 5 edição. Disponível em: https://www.prolivro.org.br/5a-edicao-de-retratos-da-leitura-no-brasil-2/a-pesquisa-5a-edicao/. Acesso em: 10 jun. 2021.

LEFFA, V. J.; COSTA, R. A. ; BEVILÁQUA, A. F. O prazer da autoria na elaboração de materiais didáticos para o ensino de línguas. In: FINARDI, K. R.; TíLIO, R.; BORGES, V.; DELLAGNELO, A.; RAMOS FILHO, E.. (Org.). Transitando e transpondo n(a) Linguística Aplicada. Campinas: Pontes, 2019, p. 267-297.

MELÃO, Dulce Helena. Ler na era digital: os desafios da comunicação em rede e a (re)construção da(s) literacia(s). Exedra, n. 3, p. 75-90, 2010. Disponível em: http://www.exedrajournal.com/docs/N3/06A-Dulce-melao_pp_75-90.pdf. Acesso em: 19 jul. 2021.

OLIVEIRA, Ana Clara. Poemas para alfabetização: a importância das rimas no aprendizado infantil. Blog: Leiturinha. Jan/ 2021. Disponível em < https://leiturinha.com.br/blog/poemas-paraalfabetizacao-a-importancia-das-rimas-no-aprendizado-infantil/> Acesso: 2 jul. 2021.

ROJO, Roxane. Alfabetização e letramento: perspectivas linguísticas. Campinas: Mercado de Letras, 1998.

RÖSING. Tania. Literatura e Identidade na era da mobilidade. Passo Fundo: UPF, 2016. 
ROSING, Tania M. K. A formação do professor e a questão da leitura. Passo Fundo: UPF, 1996.

TEZANI, Thaís Cristina. O jogo e os processos de aprendizagem e desenvolvimento: aspectos cognitivos e afetivos. Educação em Revista, Marília, v.7, n.1/2, p. 1-16, 2006. Disponível em:

http://www2.marilia.unesp.br/revistas/index.php/educacaoemrevista/article/view/603/486. Acesso em: 7 jul. 2021.

ZALUSKI, Felipe Cavalheiro; OLIVEIRA, Tarcisio Dorn de. A utilização de jogos como proposta de Metodologia Ativa: reflexões do processo de ensino e aprendizagem no ensino superior. III Seminário Internacional de Educação ao MERCOSUL. Disponível em < https://home.unicruz.edu.br/mercosul/pagina/anais/2018/3\%20-

Mostra\%20de\%20Trabalhos\%20da\%20Gradua\%C3\%A7\%C3\%A30\%20e\%20P\%C3\%B3sGradua $\%$ C3\%A7\%C3\%A30/Trabalhos\%20Completos/A\%20UTILIZA\%C3\%87\%C3\%830\%20DE \%20JOGOS\%20COMO\%20PROPOSTA\%20DE\%20METODOLOGIA\%20ATIVA\%20REFLEX\% C3\%95ES\%20DO\%20PROCESSO\%20DE\%20ENSINO\%20E\%20APRENDIZAGEM\%20NO\%20 ENSINO\%20SUPERIOR.pdf Acesso em: 7 jul. 2021. 